
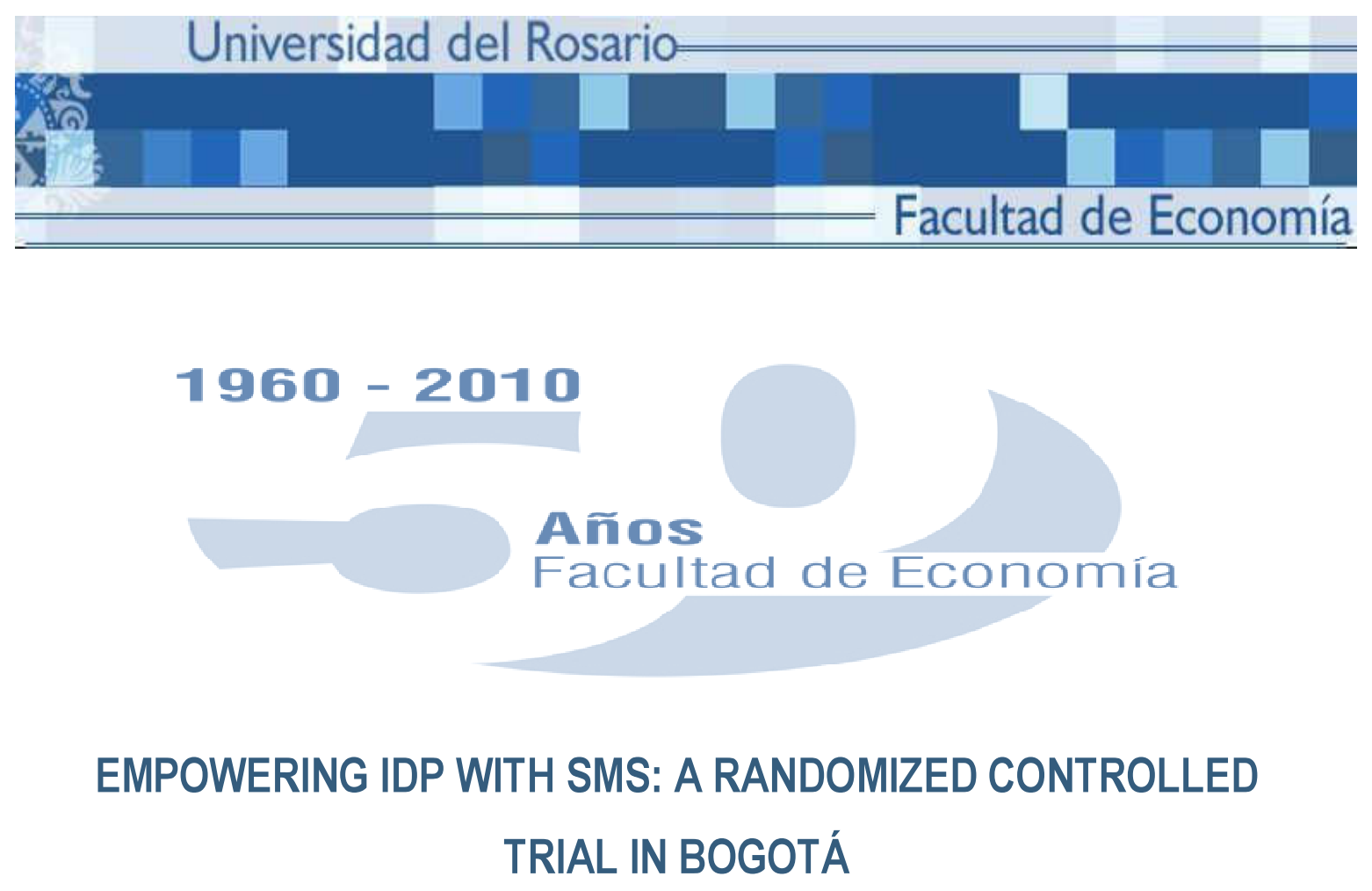

Mariana Blanco

Juan F. Vargas

SERIE DOCUMENTOS DE TRABAJO

No. 87

Julio 2010 


\title{
Empowering IDP with SMS: A Randomized Controlled Trial in Bogotá*
}

\author{
Mariana Blanco $^{\dagger} \quad$ Juan F. Vargas ${ }^{\ddagger}$
}

July 31,2010

\begin{abstract}
We carried out a randomized controlled trial in Bogotá, the recipient of Colombia's highest number of internally displaced people (IDP), to assess whether the use of SMS to communicate eligibility to social benefits fosters the welfare of victimized internal refugees. Only a fraction of IDP are eligible to benefits. We inform eligibility via SMS to a random half of IDP-households who are, and estimate the Local Average Treatment Effect of the text message on the knowledge of the benefits available to the displaced population. We show that while on average treated households know their rights better than controls, a more disaggregated analysis suggests that there is variation of awareness across benefits. The intervention was overall successful in empowering IDP and the use of SMS should be widened as a social policy instrument. However or results suggest that text messages should be complemented with other communication strategies, yet to be evaluated.
\end{abstract}

\footnotetext{
${ }^{*}$ Findings, recommendations, interpretations and conclusions expressed in this paper are those of the authors and not necessarily reflect the view of the Department of Economics of the Universidad del Rosario. We thank Angela Amaya for her assistantship and Fernando Barberi, Luis Fernando Gamboa, Clara Ramirez and Manuel Ramirez for useful discussion and help. We also thank comments from seminar participants at the IFS. We are indebted to Alejandro Garnica and Yamile Palacio from SEI, for their insights and the suggested improvements to the survey instrument.

${ }^{\dagger}$ Department of Economics, Universidad del Rosario. Cl 14 \# 4-80, of. 207, Bogotá, Colombia. Contact: mariana.blanco@urosario.edu.co

${ }^{\ddagger}$ Corresponding author. Department of Economics, Universidad del Rosario. Cl 14 \# 4-80, of. 210, Bogotá, Colombia. Contact: juan.vargas@urosario.edu.co
} 


\section{Introduction}

By most accounts, Colombia has experienced armed conflict for over four decades. Scholars identify its origin in La Violencia, a period of intense violence between the two traditional political parties from 1946 to $1966 .^{1}$ Like many other Latin American countries, Colombia witnessed the rise of guerrilla movements in the 1960s and 1970s. However, unlike the rest of the region, two of the movements, FARC and ELN, survive to date and their armed opposition is active, especially in the case of FARC. ${ }^{2}$ In addition to the rebels and the government forces, the conflict features a third armed group since the early 1980s: the so called "paramilitary forces". These right-wing militias were originally created by local elites, landowners and drug lords to counteract guerrilla extortion and ransom in the rural areas of Colombia. The paramilitaries were effectively dissipated private armies. By the mid 1990s they joined forces in order to boost their counterinsurgency effort. Although the resulting organization (called AUC after the Spanish Autodefensas Unidas de Colombia) was dismantled between 2003 and 2007 following a peace process with the administration of president Alvaro Uribe, splinter paramilitary groups including former AUC fronts are still active in the country.

This three-sided conflict has been devastating for the civilian population, especially since the creation of the AUC. Between 1988 and 2005 over 6,100 civilians died in just under 1,000 massacres perpetrated by the paramilitaries. Two thirds of the casualties during that 18-year period occurred in just one third of the time: from 1997 to 2002, during the life span of the AUC (Vargas, 2009). Indeed, paramilitaries are not primarily a clash force and try to avoid direct combat with the military and the guerrillas. Rather, they specialize in selective killings of civilians whom they presume support the rebels: over $70 \%$ of all the uncontested attacks carried out by militias have been massacres.

Violence against civilians is a strategy carried out by most armed groups fighting for territorial control (Kalyvas, 2006; Vargas, 2009). Indeed, guerrilla groups have also a sizable share of responsibility in the human security situation of the civilian population. Between 1988 and 2005 the guerrillas killed 1200 people in about 200 massacres. In fact, while allegedly the main objective of these groups is taking over political power, their actions have increasingly relied on terrorism.

The irregular tactics of all armed groups have resulted in massive numbers of internally

\footnotetext{
${ }^{1}$ See Rabassa and Chalk (2001) for a thorough review of the history of the Colombian conflict.

${ }^{2}$ While ELN is estimated to have about 4,000 combatants, FARC is said to have over 20,000.
} 
displaced people (IDP). Forced displacement has become the most dramatic social consequence of the conflict, affecting up to $90 \%$ of the country's municipalities. ${ }^{3}$ Many receiving municipalities lack the capacity of handling the inflow of refugees and $98 \%$ of displaced households are below the poverty line and face unemployment rates much higher than the rest of the population (Ibañez and Moya, 2010). Indeed, IDP are among the most vulnerable populations in Colombia and the UN has called the internal displacement situation in Colombia "the biggest humanitarian crisis in Western Hemisphere" (UN, 2004).

According to Acción Social, the government's agency in charge of social policy, by the end of 2009 almost 3.5 million people had been forcibly displaced. This represents almost $9 \%$ of the total population of the country and roughly $8 \%$ of worldwide IDP. ${ }^{4}$ According to the UN High Commissioner for Refugees (UNHCR, 2009), Colombia is the country with the largest number of IDP. Iraq and Sudan rank second and third respectively.

Ibañez (2009) conducted a survey to over 2,300 displaced households. She reports that the armed actor responsible for most displacement episodes is the guerrilla (46\%), followed by the paramilitary $(22 \%)$. Just over $1 \%$ of cases are attributed to government forces. Land disputes is the main driver of forced displacement: up to 4 million acres of land have been abandoned by the original owners. This represents 3.5\% of agricultural GDP (Ibañez and Velásquez, 2009). Colombia has today the most unequal land distribution of Latin America. The illegal expropriation of large portions of land is also explained by the need of arable land to grow coca, the main input in the production of cocaine, of which Colombia exports up to $70 \%$ of the world's supply (Mejía and Restrepo, 2009). In addition to land theft, illegal armed groups trigger displacement episodes by extorting businesses, landowners and farmers and with attempts of forcibly recruit would-be soldiers, especially among children. Intimidation of social leaders to hinder civil resistance is yet another cause of displacement. Ibañez (2009) estimates that two thirds of IDP belonged to community organizations. ${ }^{5}$

The costs of forced displacement are very large. Displaced households loose assets and social networks are weakened by the split of families and communities. ${ }^{6}$ IDP have limited

\footnotetext{
${ }^{3}$ Ibañez and Velásquez (2009) report a list of displacement episodes that have led to the majority of a town's population to flee. For instance, $95 \%$ of the people left Bojayá, in the department of Chocó. Cocorná, in Antioquia, saw $94 \%$ of its inhabitants flee and in El Tarra and Peque $82 \%$ and $78 \%$ of the population, respectively, were forced to abandon the municipality.

${ }^{4}$ This percentage is even higher if one considers a different source. According to CODHES, a Bogotá-based human rights NGOa, the Colombia share of global IDP is up to $15 \%$.

${ }^{5}$ However most of the displacement occurs individually. Around $81 \%$ of households flee by themselves and not in mass (Ibañez and Moya, 2010). This makes it difficult to identify the causes of displacement which goes against the effectiveness of social policy targeted towards IDP.

${ }^{6}$ NVS-II (2008) estimates that circa $80 \%$ of the IDP never return to their land.
} 
access to formal and informal risk-sharing mechanisms and hence are hit harder by income and consumption shocks (Ibañez and Moya, 2010). Welfare loses of displaced households are substantial, and despite modest improvements in their condition during the years following the displacement episode, most IDP will never reach their pre-displacement welfare level. According to NVS-II (2008), $43 \%$ of displaced households have a female head (which is $50 \%$ more than the national average); almost two thirds of IDP are children or teenagers so economic dependence of displaced households is large and so is child labor; and one fifth of the household heads are illiterate.

In recent years the Colombian Constitutional Court has given special attention to the needs of IDP. In Sentence T-025 of 2004, the Court recognizes that IDP are more vulnerable than the rest of the population which implies that their fundamental rights are "massively and systematically violated", and thus deserve special care from the State as well as targeted benefits. Although the Colombian government has tried hard to target such benefits and thus comply with the Court's mandate, by the end of 2007 the Court considered that the rights of IDP had not yet been reestablished.

There are many reasons why this is so, including the massive daily flow of new IDP in spite of the substantial achievements of the government against the illegal armed groups in the last few years. However, we identify one particular mechanism through which a relative low-cost intervention may boost the efficacy of public policies targeted at IDP.

Law 387 of 1997 created the Unique Registry of Displaced Population (RUPD from its Spanish acronym). The RUPD, managed by Acción Social, constitutes the official account of displaced households and it is supposed to assist the government in identifying the recipients of a set of benefits. A displaced household has the right to apply for its inclusion in the RUPD and most of them do so at the place of arrival once the displacement has taken place. The application involves a detailed account of the facts that precipitated the flee. Based on this information Acción Social assess whether the household can be included in the Registry or not. Inclusion in the RUPD entitles the declarant and her dependents to a range of benefits. $^{7}$

Nonetheless, this system has important limitations. To learn about the status of her

\footnotetext{
${ }^{7}$ It is worth noting that although being in the RUPD is a necessary condition to receive the benefits, it is not sufficient. allocation of benefits is demand-driven and often the households have to fill additional requirements. For instance public schools are mandated to offer a place to school-aged children from displaced households. However, this does not always guarantee that the child is actually enrolled in school. Sometimes this is because of a family choice (perhaps a working child is more useful for the household ) or because the household does not have enough resources to buy the books and/or uniform.
} 
application the applicant is expected to visit a specific office created by the government with the purpose of helping IDP (hereafter UAO by the Spanish Unidad de Atención y Orientación - a la población desplazada). The costs involved in this part of the process are very large. These include transportation costs, long waiting lines, and having to return several times because of information delays. In addition, the opportunity cost of spending the day at the UAO is high for people who work in the informal sector and whose daily earnings are what ensures the survival of displaced households. Indeed, it is estimated that about $70 \%$ of household included in the RUPD do not learn so and thus do not claim any of the benefits they are entitled to. Another factor that might contribute to the low demand for benefits by displaced households is the lack of information about what benefits they can claim. ${ }^{8}$

We carried out a randomized-controlled trial to asses whether the implementation a a simple communication strategy by the government, involving the use of SMS, can help IDP learning their inclusion status in the RUPD as well as the benefits they are entitled to. Hence we ultimately want to see whether information and communication technologies (ICTs) like SMS empower this particularly vulnerable population in its relationship with the government, thus helping IDP coping with the hardship displacement has put them into.

The rest of the paper is organized as follows. Section 2 describes the experimental design and section 3 reports the main results of the intervention: We give evidence that the intervention was successful in improving the awareness of IDP about their inclusion in the RUPD as well as the benefits such inclusion entitles them to. The last section concludes.

\section{Experimental design}

The ideal set up to draw causal inference on the effect of policy $X$ on outcome $Y$ is a randomized experiment. In the absence of a randomized evaluation the complexity of the environment where $X$ takes place may contaminate the causal effect on $Y$. The use of

\footnotetext{
${ }^{8}$ During the survey stage of our intervention we collected anecdotes regarding the experience of our subjects going to the UAO to get information about their status and benefits. One common story that came up was that, in order to be able to claim one of the tokens that UAO's issue prior to open the attention windows, people have to line from the night before and spend the night doing so. Some other cannot afford the transportation costs to get to the UAO (of which there are only five in Bogotá) and yet another group cannot leave their job to go to the UAO or have no one to who can take care of their children in the meanwhile. Among those who can make it to the UAO, once they finally get by the attention window they are often told to come back some other day because the their information s no yet loaded into the system. Sometimes personnel at UAOs simply are not aware of the information requested on how to access certain benefit, or are just unwilling to provide it.
} 
randomized experiments by development economists has boomed in the last decade. However randomized experiments have also raised objections. External validity, for instance, is threatened by the experiment specificity and experimental results may not be replicable in different settings. Other objections include small samples, attrition and financial costs. ${ }^{9}$

We propose the implementation of a randomized controlled trial to assess whether SMS are a cost-effective tool to empower the IDP in their relation with the government. The intervention involves an automatic alert message (SMS) sent to the registered cell-phone of the displaced household once inclusion in the RUPD is approved by Acción Social. ${ }^{10}$

The content of the message is the simplest possible and its essence is communicating to the recipient household its inclusion to the RUPD. ${ }^{11,}{ }^{12}$ Households assigned to the control group had to follow the regular procedure (i.e. show up in a collection center and wait to be assisted) to learn about the status of their application.

A post-intervention survey described in section 2.3 was conducted in order to assess the impact of the SMS strategy on the awareness of households about their inclusion in the RUPD as well as their entitlement to benefits.

\subsection{Implementation}

The intervention lasted a total of six months, from September 2009 to February 2010. The subsequent survey was carried out between March and May 2010. We worked with Acción Social, the official agency in charge registering IDP and giving them support, which includes humanitarian assistance.

The task of Acción Social was twofold and the agency's intervention was both at the beginning and at the end of the implementation process. First, Acción Social provided us with the information on the newly included IDP in the Registry. We used that information to randomly allocate the households into treatment and control. The resulting list by treatment

\footnotetext{
${ }^{9}$ Still, in recent years an influential group of development economists has advocated in favor of randomized evaluations (Banerjee and Duflo, 2008).

${ }^{10} \mathrm{It}$ is estimated that over $98 \%$ of displaced households have cell phones (NVS-II, 2008). This is because penetration of mobile telephony is very large in developing countries, especially in the case of our target population, which is highly mobile for its very displacement condition.

${ }^{11}$ The actual text treated households received was: ACCIÓN SOCIAL informa: Ha sido incluido en el Registro Único de Población Desplazada, favor acercarse a la UAO más cercana para mayor información.

${ }^{12} \mathrm{~A}$ second SMS with a reminder that inclusion in the RUPD entitled to benefits was also sent to half of those receiving the baseline treatment. However due to a very reduced sample of subjects taking part in the follow-up survey who actually received this second message, we have no power no make any analysis involving the impact of this additional piece of information. Section 2.1 gives details of the sources of sample loss we faced throughout the intervention and assesses whether this is likely to generate any bias.
} 
status was sent back to Acción Social, who then sent treated subjects the SMS.

While the government agency showed enthusiasm and commitment during the design of the trial, in actuality the agency was rather negligent regarding the project, which costed us amidst other things long delays in the implementation and large sample-size losses. Unfortunately, given the monopoly of Acción Social over the RUPD, we did not have a choice but to work under the adverse and constantly changing conditions that the agency unilaterally set.

\subsection{Sample issues}

\subsubsection{Declaration}

At the beginning of the intervention we estimated that by the end of the evaluation we would be able to have a sample of about 1,200 displaced households. Dramatically, the actual sample of surveyed households ended up being 218, less than $20 \%$ of the target (see Table 1). The first source of sample loss is explained by a lower flow of IDP arriving to Bogotá and declaring their condition. Using figures provided to us by Acción Social officials during the design stage of the experiment we estimated a lower bound of 7,000 households to declare in Bogotá during the six months the intervention was planned to last. ${ }^{13}$ However, as reported in the first column of Table 1, actaul declarants were 4,108 about $60 \%$ of the magnitude expected.

Table 1: Difference Between Estimated and Actual Sample

\begin{tabular}{lcccc}
\hline \hline & Declarants & Included & Consent & After attrition \\
\hline \multirow{2}{*}{ Estimated } & \multirow{2}{*}{7,000} & 4,900 & 2,450 & 1,225 \\
& & $70 \%$ & $50 \%$ & $50 \%$ \\
\multirow{2}{*}{ Realized } & 4,108 & 1,433 & 607 & 218 \\
\multirow{2}{*}{ Loss } & & $35 \%$ & $42 \%$ & $36 \%$ \\
\hline \hline
\end{tabular}

\footnotetext{
${ }^{13}$ Acción Social reported an average of 250-300 new households arriving in Bogotá every week.
} 


\subsubsection{RUPD inclusion}

The second source of sample shrinkage compromises the information provided to us by Acción Social even further. The institution claimed an average acceptance of declarants into the RUPD of $70 \%$. As shown in column 2 of Table 1, we then expected a sample of included of about 4,900 households. Given the actual number of declarants, and inclusion rate of $70 \%$ would have yielded 2,875 included households. Sadly, the ex post acceptance rate of Acción Social during the intervention period was barely half of what they announced. This resulted in a sample of just over 1,400 households included: By this time we were counting with only $30 \%$ of the 4,900 households we had planned. And further losses were still to take place.

\subsubsection{Consent form}

Because IDP are a vulnerable population that has been targeted and victimized, the Office of the Colombian Public Prosecutor mandated that any agent wishing to contact displaced individuals via their cell phone or by other means must have their written consent. Thus we first went through a pre-intervention stage whereby we provided every public office taking declarations from IDP wishing to be included in the RUPD in Bogotá with a package of consent forms, according to the estimated flow of IDP to each office. The consent form (the model of which is attached in Appendix B, was to be attached to the displacement declaration and sent back to Acción Social, which in turn would forward it to us for our team to selectout from the universe of RUPD-included households only those who had consented and leave the rest out of the sample since we could not send them any SMS without consent.

Because of the vulnerability of IDP households and the constant fear they live in after having been victims of the armed conflict, we did not expect a huge consent rate. This, together with the complex logistics involving the distribution of consent forms throughout the city and the training of officials taking declarations on how to use them, made us make a conservative estimate of the consent rate of about $50 \%$. It turns out that we were relatively accurate in our prior: as reported in column 3 of Table 1 the actual consent rate was $42 \%$. In short, many IDP were reluctant to sign the form, and many other were not even offered the chance to do so despite numerous awareness meetings we held with the implicated officials.

\subsubsection{Attrition}

Last but no least the already decimated sample size was further cut by attrition. There are two reasons why attrition was arguably expected to be rather large. On the one hand IDP 
households migrate at much higher rates than any other population, which makes them less likely to be found by the survey team. IDP tend to declare in the place they first arrive after the displacement episode but by no means they will necessarily stay and settle in the same town. Forced displacement is an unplanned event and fleeing families usually move to the nearest safe (usually urban) area. While a small portion of IDP return to their lands after they hear that the security situation seems to have improved, most of those who move go to neighbor towns, big cities where they hope to find economic opportunities, or places where they have family or social networks that can help them re-settle and start a new life.

On the other hand, contact to households to-be-surveyed was mainly done by cell-phone (because this is the way they authorized to be contacted in the consent form) and this involves many risks including phones shared with family or neighbors and lost phones. Our attrition rate estimate fell short of the actual attrition. While we though we may end up loosing up to $50 \%$ of households, the sample was actually shorted by over $60 \%$ (Table 1 , column 4).

During the survey stage we were able to individuate qualitatively the most common reasons for attrition. These include:

1. Contact details included in the consent form were no longer up to date. There were many instances in which the registered cell phone was no longer in use, forwarded calls systematically to the mailbox, or belonged to a different person unrelated with the subject of interest. Even in such cases our survey team went to the registered address only to find out the majority of time that our subjects had left or that they never lived there.

2. Mobility of IDP. Due to both budget constraints and the focus of the trial in Bogotá our survey team was not able to track subjects that had left to other towns.

3. Appointment reneger. The survey team contacted the subjects in advance to set an appointment for the interview. Subjects in many cases reneged ex post on the previously established appointment arguing they could not leave their jobs or simply giving false addresses. The former has to do with the fact that most IDP do not have stable jobs. Some work intermittently in various activities offered to them informally and for short periods. Interview appointments are understandably given less priority than overlapping jobs, obtained after setting up the appointment. On the other hand, the provision of false addresses probably has to do with the fact that IDP have been victimized and hence tend to be suspicious and timorous. 


\subsubsection{Unbiased loss}

Overall the characteristics and complexity of the target population, together with the unanticipated low reliability of our partner institution, made us be able to complete the intervention only with a low number of subjects. In this subsection we provide evidence that the reduction the sample suffered in the various stages summarized by Table 1 is not likely to have produced any significant bias in the estimates we report on section 3 .

The database provided to us by Acción Social contained the full list of declarant IDP who had arrived to Bogotá during the period of intervention ${ }^{14}$, information on who were included and who not, and information about the consent form. This was the basic input we needed to perform the randomization and produce the list of declarant+included+consenting IDP to be sent the informative SMS. We also requested a set of baseline characteristics to be included for the whole sample, and we managed to get only a few. We use these four baseline variables to assess whether there is evidence of systematic differences between the population subsamples of the different stages that led the sample to grow smaller.

We start with the gender of the household representative who declared the IDP status. Panel A of Table 2 shows the share of women among the declarants who were included in the RUPD and those who were not. Overall over half of the declarants are women which is consistent with the aforementioned fact that IDP have a large proportion of female-headof-household. Moreover, the proportion of females is very similar between the included and the not-included, and a t-test suggests that the 1.7 percentage points difference is not significant at conventional levels ${ }^{15}$.

In turn, Panel B of Table 2 limits the analysis to the sample of included IDP and compares the share of females between those declarants who signed the consent form and those who did not. There is only a non-significant 0.3 percentage points difference. Finally, Panel C looks at the sample of included who gave consent and assess potential biases caused by attrition by comparing the share of women who participated in the follow-up survey and those who were not found for an interview by the survey team. The difference in this case is somewhat larger (6.7 percentage points) but still not significant.

Table 3 repeats the exercise of Table 2 but looks at the average number of beneficiaries

\footnotetext{
${ }^{14}$ Acción Social has no information of non-declarant IDP, and actually does not even considers them to be displaced

${ }^{15}$ Note however that in general the difference between RUPD-included and not included IDP, in terms of certain baseline characteristics, should not be expected to be statistically indistinguishable from zero. This owes to the fact that inclusion is not random and responds to a particular set of criteria applied by by Acción Social.
} 
Table 2: Differences in Declarant's Gender Across Samples (share of female)

Panel A: RUPD-included vs. not included

$\begin{array}{ccc}\text { Included } & \text { Not included } & \text { Difference } \\ 0.561 & 0.543 & 0.017 \\ (0.013) & (0.010) & (0.016)\end{array}$

Panel B: Consent vs. no consent (within included)

$\begin{array}{ccc}\text { Consent } & \text { No consent } & \text { Difference } \\ 0.563 & 0.559 & 0.003 \\ (0.020) & (0.017) & (0.027)\end{array}$

Panel C: Interviewed vs. not found (within included \& given consent)

\begin{tabular}{ccc} 
Interviewed & Not found & Difference \\
0.606 & 0.539 & 0.067 \\
$(0.033)$ & $(0.025)$ & $(0.042)$ \\
\hline
\end{tabular}

per declaration ${ }^{16}$. Panel A shows that Acción Social tends on average to include households with less beneficiaries. While the average number of beneficiaries for included households is 2.1 that of not-included is almost 2.3 and the difference is significant at the $10 \%$ level. This is however not a problem because the differences between included and excluded households can neither be controlled by us nor are part of the matter we want to evaluate. These differences depend on the particular guidelines for inclusion of Acción Social.

What does matter to us, in terms of bias that may be associated to the processes that reduced the sample, are the differences between households who consent and those who did not, as well as the differences between the surveyed households and those who were not found for interview. Panels B and C of Table 3 show that there are no such significant differences in terms of number of beneficiaries in neither case.

Differences across samples for two other variables: 'region of origin of the IDP' and 'cause

\footnotetext{
${ }^{16}$ Every declarant 'attaches' to her declaration a certain number of beneficiaries, comprised by the number of households members who flee together and for whom the facts reported in the declaration apply.
} 
Table 3: Differences in the Number of Beneficiaries per Declarant Across Samples

Panel A: RUPD-included vs. not included

$\begin{array}{ccc}\text { Included } & \text { Not included } & \text { Difference } \\ 2.105 & 2.267 & -0.162 \\ (0.066) & (0.047) & (0.083)^{*}\end{array}$

Panel B: Consent vs. no consent (within included)

$\begin{array}{ccc}\text { Consent } & \text { No consent } & \text { Difference } \\ 2.163 & 2.043 & 0.120 \\ (0.088) & (0.099) & (0.132)\end{array}$

Panel C: Interviewed vs. not found (within included \& given consent)

\begin{tabular}{ccc} 
Interviewed & Not found & Difference \\
2.235 & 2.123 & 0.111 \\
$(0.154)$ & $(0.107)$ & $(0.184)$ \\
\hline \hline
\end{tabular}

of displacement' are reported in Appendix A. In terms of region of origin the only significant difference is that between those included in the RUPD and those who were not (Table A$8)^{17}$. Again, this is not a problem because the inclusion is $100 \%$ jurisdiction of Acción Social and analyzing its determinants is not part of this paper. More importantly there are no significant differences in terms of region of origin between the IDP who signed the consent form and those who did not, and between those found for the interview and those who were not (Tables A-9 and A-10 respectively).

Results are similar for the case of cause of displacement: The only significant difference is that between those included and those not (Table A-11) ${ }^{18}$. In the other cases we cannot reject the null hypothesis that the samples come from the same distribution of 'causes' (Tables A-12 and A-13 respectively).

\footnotetext{
${ }^{17}$ The statistic of the non-parametric chi-squared test (with 32 degrees of freedom) is 93.741 with $p$-value of 0.000 .

${ }^{18}$ The statistic of the chi-squared test $(14)$ is $51.067(p$-value $=0.000)$.
} 


\subsection{Follow-up survey}

There is no reliable and comprehensive official information system to monitor the actual awareness and take-up of social benefits by included IDP. Therefore we conducted a followup survey to identify whether the use of SMS to communicate inclusion in the RUPD had a significant impact on benefit awareness and knowledge.

We first run a pilot on March 12 and 13, 2010, that allowed us to adjust the original questionnaire (see section 2.3.1) and assess the length of the interview. Then the actual field work took place between April $7^{\text {th }}$ and May 19th 2010.

Of the 218 households (902 people) surveyed exactly half are treated and half control. Since the location of survey respondents was not made by trying to keep a balanced sample, the fact that the originally assigned proportions of treated and control are kept unchanged gives further evidence that attrition rates are not systematically related with the treatment status and hence are not biasing our results.

\subsubsection{Questionnaire}

In order to measure the impact of the SMS intervention on the awareness and take up of benefits our survey includes questions regarding: i) whether households know they were included in the RUPD ${ }^{19}$; ii) whether they knew any or some of the benefits being in the RUPD entitled them to; and iii) whether they had actually claim any of them. In addition, we included a complete set of questions that allow us to build a socioeconomic profile of the displaced household which we use as controls in our empirical analysis (section 3).

The full questionnaire is divided in eight parts and includes questions verifying the IDP condition and giving information about the displacement (Part I); questions that characterize the current and past living conditions and compares them (Part II); questions that characterize the household with all its members including human capital (education and health conditions) and employment status (Part III); questions on awareness of and access to social benefits (Part IV); questions on asset ownerships (Part V); questions on social capital (Part VI); questions on cell-phone and SMS access and literacy (Part VII); and questions on civic participation (Part VIII). It is indeed a rather complete questionnaire that allows us assess the general impact of the use of SMS (Part IV) but also study the determinants

\footnotetext{
${ }^{19}$ We cannot guarantee that text messages sent to the registered cell-phones of treated households will actually be received and read by the interested party. Thus with the answer to this question we are able to measure compliance and then apply instrumental-variable methods to compute the causal effect of being assigned to treatment on the awareness and take up of benefits.
} 
of differential impact rates (Parts II, III, V and VI), and the mechanisms behind our results (Part VII).

\section{Results}

\subsection{Descriptive statistics}

Table 4 shows that the randomization was successful in generating no significant difference between treated and control households in terms of a full battery of variables. We divide these in four categories: cause of displacement, perpetrator, household characteristics and characteristics of the declarant. Because the t-tests reveal no significant difference between treated and control units in any of the observable pre-treatment characteristics, the ignorability assumption of the Rubin Causal Model (Rubin, 1974) holds. Given additionally the fact that every unit had equal chance of receiving treatment a priori, then we believe that the effect of the SMS treatment on the post-treatment outcome variables is indeed causal.

\subsection{Treatment effect}

Panel A of Table 5 compares the inclusion awareness of treated and control units. This outcome was constructed from respondents' answer to the question: "Do you know if you have been included to the RUPD?". While $86 \%$ of treated households declared to be aware of their inclusion, only $71 \%$ of the control did (recall that for a household to be in our sample it necessarily had to be included in the RUPD). The 15 percentage point difference $(20 \%)$ difference is significant at the $1 \%$.

Given ignorability (see Table 4), the mean-difference is a good estimate of the causal effect. However, the regression counterpart of this comparison is useful insofar as adding controls help improving the statistical precision of the estimate (Angrist and Pischke, 2008). Table 6 reports the Probit estimates of the impact the treatment on the RUPD-inclusion awareness. While the estimate presented in column 1 includes no controls, columns 2 through 5 include all the controls described on Table 4 one extra category at a time: Column 2 includes controls regarding the cause of displacement; column 3 adds perpetrator dummies; columns 4 and 5 add household and declarant characteristics respectively. In all cases the estimate of the causal effect is positive and significant at the $1 \%$ level. The magnitude of the coefficient indicates that the treatment increases the awareness of inclusion in $10 \%$. 
Table 4: Descriptive Statistics

\begin{tabular}{|c|c|c|c|}
\hline & $\begin{array}{l}\text { Treated } \\
(\mathrm{N}=109)\end{array}$ & $\begin{array}{l}\text { Control } \\
(\mathrm{N}=109)\end{array}$ & Difference \\
\hline \multicolumn{4}{|c|}{ Panel A: Cause of displacement } \\
\hline Threats & $\begin{array}{c}0.798 \\
(0.039)\end{array}$ & $\begin{array}{c}0.734 \\
(0.043)\end{array}$ & $\begin{array}{c}0.064 \\
(0.057)\end{array}$ \\
\hline Killings & $\begin{array}{c}0.092 \\
(0.028)\end{array}$ & $\begin{array}{c}0.11 \\
(0.03)\end{array}$ & $\begin{array}{l}-0.018 \\
(0.041)\end{array}$ \\
\hline Attack to town & $\begin{array}{c}0.009 \\
(0.009)\end{array}$ & $\begin{array}{c}0.018 \\
(0.013)\end{array}$ & $\begin{array}{l}-0.009 \\
(0.016)\end{array}$ \\
\hline Forced recruitment & $\begin{array}{c}0.083 \\
(0.026)\end{array}$ & $\begin{array}{c}0.083 \\
(0.026)\end{array}$ & $\begin{array}{c}0.000 \\
(0.037)\end{array}$ \\
\hline Other & $\begin{array}{c}0.018 \\
(0.013)\end{array}$ & $\begin{array}{c}0.055 \\
(0.022)\end{array}$ & $\begin{array}{l}-0.018 \\
(0.025)\end{array}$ \\
\hline \multicolumn{4}{|l|}{ Panel B: Perpetrator } \\
\hline Paramilitaries & $\begin{array}{c}0.266 \\
(0.043)\end{array}$ & $\begin{array}{c}0.33 \\
(0.045)\end{array}$ & $\begin{array}{l}-0.064 \\
(0.062)\end{array}$ \\
\hline Guerrillas & $\begin{array}{c}0.624 \\
(0.047)\end{array}$ & $\begin{array}{c}0.642 \\
(0.046)\end{array}$ & $\begin{array}{l}-0.037 \\
(0.066)\end{array}$ \\
\hline Not known & $\begin{array}{c}0.128 \\
(0.032)\end{array}$ & $\begin{array}{c}0.073 \\
(0.025)\end{array}$ & $\begin{array}{c}0.055 \\
(0.041)\end{array}$ \\
\hline \multicolumn{4}{|c|}{ Panel C: Household characteristics } \\
\hline Size & $\begin{array}{c}3.624 \\
(0.194)\end{array}$ & $\begin{array}{c}3.991 \\
(0.246)\end{array}$ & $\begin{array}{l}-0.367 \\
(0.314)\end{array}$ \\
\hline No. displacement episodes & $\begin{array}{c}1.202 \\
(0.052)\end{array}$ & $\begin{array}{c}1.239 \\
(0.055)\end{array}$ & $\begin{array}{l}-0.037 \\
(0.076)\end{array}$ \\
\hline Assets prior to disp & $\begin{array}{c}0.633 \\
(0.046)\end{array}$ & $\begin{array}{c}0.679 \\
(0.045)\end{array}$ & $\begin{array}{l}-0.046 \\
(0.065)\end{array}$ \\
\hline Ethnicity: Afro-Colombian & $\begin{array}{c}0.064 \\
(0.024)\end{array}$ & $\begin{array}{c}0.092 \\
(0.028)\end{array}$ & $\begin{array}{l}-0.028 \\
(0.036)\end{array}$ \\
\hline Ethnicity: Indigenous & $\begin{array}{l}0.046 \\
(0.02)\end{array}$ & $\begin{array}{c}0.046 \\
(0.02)\end{array}$ & $\begin{array}{c}0.000 \\
(0.028)\end{array}$ \\
\hline Ethnicity: Other & $\begin{array}{c}0.89 \\
(0.03)\end{array}$ & $\begin{array}{c}0.862 \\
(0.033)\end{array}$ & $\begin{array}{c}0.028 \\
(0.045)\end{array}$ \\
\hline \multicolumn{4}{|c|}{ Panel D: Declarant's characteristics } \\
\hline $\operatorname{Sex}(1=$ woman $)$ & $\begin{array}{c}0.633 \\
(0.046)\end{array}$ & $\begin{array}{c}0.606 \\
(0.047)\end{array}$ & $\begin{array}{c}0.028 \\
(0.066)\end{array}$ \\
\hline Age & $\begin{array}{l}36.972 \\
(1.267)\end{array}$ & $\begin{array}{l}36.11 \\
(1.16)\end{array}$ & $\begin{array}{c}0.862 \\
(1.718)\end{array}$ \\
\hline Education & $\begin{array}{c}2.358 \\
(0.134)\end{array}$ & $\begin{array}{c}2.367 \\
(0.137)\end{array}$ & $\begin{array}{l}-0.009 \\
(0.192)\end{array}$ \\
\hline Community network & $\begin{array}{l}19.037 \\
(0.018)\end{array}$ & $\begin{array}{c}0.055 \\
(0.022)\end{array}$ & $\begin{array}{l}-0.018 \\
(0.028)\end{array}$ \\
\hline
\end{tabular}


Table 5: Inclusion and benefit awareness

\begin{tabular}{|c|c|c|c|c|c|c|}
\hline & \multicolumn{3}{|c|}{ By treatment status } & \multicolumn{3}{|c|}{ By inclusion awareness } \\
\hline & $\begin{array}{c}\text { Treated } \\
(1) \\
\end{array}$ & $\begin{array}{c}\text { Control } \\
(2) \\
\end{array}$ & $\begin{array}{c}\text { Difference } \\
(3) \\
\end{array}$ & $\begin{array}{c}\text { Treated } \\
(4) \\
\end{array}$ & $\begin{array}{c}\text { Control } \\
(5) \\
\end{array}$ & $\begin{array}{c}\text { Difference } \\
(6) \\
\end{array}$ \\
\hline \multicolumn{7}{|c|}{ Panel A: RUPD-inclusion } \\
\hline & $\begin{array}{c}0.862 \\
(0.008)\end{array}$ & $\begin{array}{c}0.716 \\
(0.010)\end{array}$ & $\begin{array}{c}0.146 \\
(0.012)^{* * *}\end{array}$ & & & \\
\hline \multicolumn{7}{|c|}{ Panel B: Benefits awareness } \\
\hline All & $\begin{array}{c}0.336 \\
(0.014)\end{array}$ & $\begin{array}{c}0.314 \\
(0.013)\end{array}$ & $\begin{array}{c}0.023 \\
(0.019)\end{array}$ & $\begin{array}{c}0.350 \\
(0.011)\end{array}$ & $\begin{array}{c}0.231 \\
(0.019)\end{array}$ & $\begin{array}{c}0.119 \\
(0.023)^{* * *}\end{array}$ \\
\hline Medical care & $\begin{array}{c}0.489 \\
(0.024)\end{array}$ & $\begin{array}{c}0.433 \\
(0.024)\end{array}$ & $\begin{array}{c}0.055 \\
(0.034)^{*}\end{array}$ & $\begin{array}{c}0.483 \\
(0.019)\end{array}$ & $\begin{array}{c}0.380 \\
(0.036)\end{array}$ & $\begin{array}{c}0.102 \\
(0.017)^{* * *}\end{array}$ \\
\hline Food & $\begin{array}{c}0.523 \\
(0.048)\end{array}$ & $\begin{array}{c}0.569 \\
(0.048)\end{array}$ & $\begin{array}{l}-0.046 \\
(0.068)\end{array}$ & $\begin{array}{c}0.581 \\
(0.038)\end{array}$ & $\begin{array}{c}0.413 \\
(0.073)\end{array}$ & $\begin{array}{c}0.168 \\
(0.082)^{* *}\end{array}$ \\
\hline Housing & $\begin{array}{c}0.436 \\
(0.034)\end{array}$ & $\begin{array}{c}0.385 \\
(0.033)\end{array}$ & $\begin{array}{c}0.050 \\
(0.047)\end{array}$ & $\begin{array}{c}0.459 \\
(0.027)\end{array}$ & $\begin{array}{c}0.228 \\
(0.044)\end{array}$ & $\begin{array}{c}0.231 \\
(0.057)^{* * *}\end{array}$ \\
\hline Supplies & $\begin{array}{c}0.087 \\
(0.014)\end{array}$ & $\begin{array}{c}0.094 \\
(0.014)\end{array}$ & $\begin{array}{l}-0.007 \\
(0.019)\end{array}$ & $\begin{array}{c}0.105 \\
(0.012)\end{array}$ & $\begin{array}{c}0.038 \\
(0.014)\end{array}$ & $\begin{array}{c}0.067 \\
(0.024)^{* * *}\end{array}$ \\
\hline
\end{tabular}

Notes: ${ }^{*}$ Significant at $10 \%,{ }^{* *}$ significant at $5 \%,{ }^{* * *}$ significant at $1 \%$.

Table 6: Effect of treatment on inclusion awareness - Probit regression

$\begin{array}{lccccc}\text { Treatment } & 0.217 & 0.229 & 0.231 & 0.252 & 0.253 \\ \text { Controls } & (0.030)^{* * *} & (0.030)^{* * *} & (0.030)^{* * *} & (0.030)^{* * *} & (0.030)^{* * *} \\ \text { Cause of disp. } & & \checkmark & \checkmark & \checkmark & \checkmark \\ \text { Perpetrator } & & & \checkmark & \checkmark & \checkmark \\ \text { Househols charact. } & & & \checkmark & \checkmark \\ \text { Declarant charact. } & & & & \mathbf{V}\end{array}$

Notes: ${ }^{*}$ Significant at $10 \%,{ }^{* *}$ significant at $5 \%,{ }^{* * *}$ significant at $1 \%$.

Robust standard errors in parentheses 
The positive and robust effect of the treatment on the awareness of inclusion in the RUPD is good news. On the one hand sending an informative SMS is a very cheap policy intervention and almost the totality of potential beneficiaries have the means for receiving it. On the other, increasing knowledge about whether or not people are entitled to receive benefits is the first step towards improving access and hence the welfare of the vulnerable population that IDP are. We can, however, explore wether the impact of the intervention goes further in achieving this more ambitious objective by looking at the actual awareness of the IDP about the different benefits they are allowed to request once they are included in the RUPD.

Panel B of Table 5 takes a first look at this by showing the means of benefit awareness. For conciseness in the analysis and exposition we aggregate the full set of Emergency Humanitarian Help (EHH) benefits (Decree 2569 of 2000) in five indicators: i) Medical care which aggregates the right to medical assessment, psychological assessment, emergency medical care, and medicines; ii) Food is the right to receive food supplies; iii) Housing which aggregates temporal housing and rent subsidy; iv) Supplies which aggregates kitchen and cleaning supplies, beds and mattresses and clothing; and v) All and indicator that aggregates the previous four.

Columns (1), (2) and (3) of Table 5 (Panel B) compare the awareness means across treatment status. As it turns out, the only significant difference (at the $10 \%$ level) is that of Medical care. Treated households are 6 percentage points (13\%) more aware than the control about their right to request benefits related to medical care.

The fact that the difference is not significant for the rest of benefit indicators may be due to non-compliance. Indeed for the reasons explained above related with the nature of the target population it is very likely that a relevant share of treated households had not received the SMS. This is somewhat confirmed by the large (64\%) attrition rate, which evidences that many cell-phones were lost or not carried by the subjects. To explore this further columns (4), (5) and (6) of Table 5 look at the differences in benefit-awareness means not by treatment status but by the self-reported awareness of being included in the RUPD. The difference reported in column (6) suggests that households who know they are included (recall that all households in our sample are) are on average much more aware of their rights than households who do not even know about their inclusion (up to 23 percentage points in the case of housing!).

The stark differences between column (3) and column (6) suggests an IV-type empirical approach. The OLS counterpart of column (6) would be biased because awareness of RUPD 
inclusion is likely to be correlated with unobservables that also affect knowledge of benefits. Suppose that the causal effect of inclusion $(W)$ on the knowledge of benefits $(Y)$ is given by the parameter $\theta$ in the regression:

$$
Y=\alpha+\theta W+\varepsilon
$$

How can the causal effect be estimated? Define $Z$ as the treatment assignment: $Z=1$ for treated households and $Z=0$ for control. Then the expected value of $Y$, given $Z=1$ is

$$
\begin{aligned}
E(Y \mid Z=1) & =E(\alpha \mid Z=1)+\theta E(W \mid Z=1)+E(\varepsilon \mid Z=1) \\
& =\alpha+\theta E(W \mid Z=1)
\end{aligned}
$$

and that given $Z=0$,

$$
\begin{aligned}
E(Y \mid Z=0) & =E(\alpha \mid Z=0)+\theta E(W \mid Z=0)+E(\varepsilon \mid Z=0) \\
& =\alpha+\theta E(W \mid Z=0)
\end{aligned}
$$

Substracting the two equations yields:

$$
E(Y \mid Z=1)-E(Y \mid Z=0)=\theta E(W \mid Z=1)-E(W \mid Z=0)
$$

and hence and estimate for the causal effect $\widehat{\theta}$ follows directly:

$$
\widehat{\theta}=\frac{\widehat{E}(Y \mid Z=1)-\widehat{E}(Y \mid Z=0)}{\widehat{E}(W \mid Z=1)-\widehat{E}(W \mid Z=0)}
$$

So the IV-estimate of the causal effect is in essence the ratio of the mean difference of the rate of benefit knowledge to the mean difference of inclusion awareness, both differences computed across treatment status. This IV estimator is called Wald estimator, and it holds in cases like ours, when the instrument is binary. It is also noteworthy that $\widehat{\theta}$ needs $E(W \mid Z=1) \neq E(W \mid Z=0)$. This means that the treatment status must be a good instrument for inclusion awareness, something which we know is true, as shown by Panel A of Table 5 and by Table 6 .

The causal effect computed this way is called Local Average Treatment Effect (LATE), 
Table 7: Effect of treatment on benefits awareness - Wald estimator

\begin{tabular}{lccccc}
\hline & & & & & \\
& All benefits & Medical care & Food & Housing & Supplies \\
\hline \hline \multirow{2}{*}{ IV-Inclusion awareness } & 0.621 & 1.136 & -0.651 & 1.191 & -0.086 \\
& $(0.360)^{*}$ & $(0.502)^{* *}$ & $(1.073)$ & $(0.747)$ & $(0.841)$ \\
Controls $\checkmark$ & & & & & \\
\hline \hline
\end{tabular}

Notes: $*$ Significant at $10 \%, * *$ significant at $5 \%, * * *$ significant at $1 \%$.

Robust standard errors in parentheses

and it provides information only on the impact of the treatment on the IDP households affected by the instrument. ${ }^{20}$

Table 7 reports the results for the 5 set of benefits as defined above. All regressions include the full set of controls and report robust standard errors. Importantly, the treatment increases significantly (at the 10\% level) the awareness of the aggregate of all benefits. The economic magnitude of the IV-Probit coefficient suggests that treatment increases awareness by $25 \%$. This is, however, driven by the large and positive impact of the treatment on the awareness of Medical care benefits. Treatment increases the knowledge of IDP about the right of Medical care by $45 \%$ (significant with $95 \%$ confidence).

Treatment does not increase the awareness about the right to either Food, Supplies, or Housing, although the effect for the latter is positive and marginally significant at the $10 \%$ level $(\mathrm{p}$-value $=0.11){ }^{21}$

\section{Conclusion}

We presented evidence from a randomized-controlled trial that the use of SMS as channel to improve the communication of the government with beneficiaries of social programs can empower vulnerable populations and substantially increase their welfare. In this respect SMS are a potentially effective instrument for social policy.

\footnotetext{
${ }^{20}$ LATE is generally different than the population treatment. But is the best we can do give the aforementioned non-compliance.

${ }^{21}$ We do not analyze the effect of treatment on the take-up of the different benefits. The reason for this is the fact that while awareness can be influenced by an improvement on communication, the actual request of benefits is a choice of the IDP so the relevant variable to look at is awareness.
} 
Our findings are specific to the context of Colombia: a country that has experienced internal conflict for over four decades, that has the world's largest number of internal refugees and where this population is the most vulnerable social group. We show that an intervention as cheap as sending a text message communicating to vulnerable households their entitlement to social benefits increases their awareness and through this channel their welfare.

The magnitude of our results, together with the low cost of the intervention, suggest that the incoming government of Colombia should prioritize nation-wide escalation of our Bogotá pilot, thereby boosting the reception of social benefits of IDP, in the context of a system that by design is demand-based. This will no doubt become a top social program, especially because the Constitutional Court, which has in recent years become a watchdog of the rights of IDP, will not cease compelling the Colombian government to find mechanisms to ensure social priority of the victims of the armed conflict.

\section{References}

Angrist, J., and J. Psichke (2008). Mostly Harmless Econometrics, Princeton University Press.

Banerjee, A., and E. Duflo (2008). "The Experimental Approach to Development Economics" mimeo, MIT.

Blanco, M., Gamboa, L.F and J. F. Vargas (2009). "Empowering Internally Displaced People in Colombia through the Use of ICTs: Design and Implementation".

Ibáñez, A. M. (2009). "Forced displacement in Colombia: Magnitude and Causes", The Economics of Peace and Security Vol. 4 No. 1.

Ibañez, A. M. and A. Velásquez (2009). "Identifying Victims of Civil Conflicts: An Evaluation of Forced Displaced Households in Colombia", Journal of Peace Research Vol. 46(3): 431-451.

Ibáñez, A. M., and A. Moya (2010). "Vulnerability of Victims of Civil Conflicts: Empirical Evidence for the displace Population in Colombia", World Development Vol. 38(4): 647-663.

Mejía, D. and P. Restrepo (2009) "The war on Illegal Drug Production and Trafficking: An economic evaluation of Plan Colombia, unpublished manuscript.

NVS-II (2008). "Second National Verification Survey on Forced Displacement", carried out by Comisión de Seguimiento de la Política Pública sobre Desplazamiento Forzado and Centro de Investigaciones para el Desarrollo (CID). 
Rabassa, A., and P. Chalk (2001). Colombian Labyrinth: The Synergy of Drugs and Insurgency and Its Implications for Regional Stability. RAND.

Rubin, D. (1974). "Estimating Causal Effects of Treatments in Randomized and Nonrandomized Studies", Journal of Educational Psychology 66(5): 688-701.

UN (2004). "Colombia has biggest humanitarian crisis in western hemisphere" United Nations News Service, May $10^{\text {th }}$.

UNHCR (2009). Statistical Yearbook 2008. Available at: http://www.unhcr.org/4bcc5bb79.html (last access April 30, 2010).

Vargas, J. F. (2009). "Military Empowerment and Civilian Targeting in Civil War" Documentos de trabajo 61, Universidad del Rosario, Facultad de Economía. 
Appendix A Further sample comparisons 
Table A-8: Differences in region of origin: RUPD-included vs. not included

\begin{tabular}{lccc}
\hline & & & \\
Region & RUPD-included & Not-included & Difference \\
\hline \hline & & & \\
Amazonas & 0.28 & 0.13 & 0.15 \\
Antioquia & 8.11 & 5.94 & 2.17 \\
Arauca & 2.24 & 1.36 & 0.88 \\
Atlántico & 0.84 & 1.49 & -0.65 \\
Bogotá & 0.42 & 1.87 & -1.45 \\
Bolívar & 2.38 & 4.59 & -2.21 \\
Boyacá & 1.26 & 2.33 & -1.07 \\
Caldas & 1.12 & 3.29 & -2.18 \\
Caquetá & 5.45 & 3.75 & 1.71 \\
Casanare & 0.56 & 0.84 & -0.28 \\
Cauca & 3.22 & 2.65 & 0.57 \\
Cesar & 1.96 & 2.33 & -0.37 \\
Chocó & 3.22 & 3.23 & -0.01 \\
Cundinamarca & 3.22 & 6.46 & -3.24 \\
Córdoba & 3.64 & 5.68 & -2.05 \\
Guainía & 0 & 0.19 & -0.19 \\
Guajira & 0.84 & 1.16 & -0.32 \\
Guaviare & 2.10 & 1.42 & 0.68 \\
Huila & 10.63 & 6.01 & 4.62 \\
Magdalena & 2.38 & 2.84 & -0.46 \\
Meta & 5.17 & 5.17 & 0.01 \\
Nariño & 6.43 & 6.78 & -0.35 \\
Norte de Santander & 1.54 & 0.97 & 0.57 \\
Putumayo & 2.52 & 1.87 & 0.64 \\
Quindio & 0.14 & 0.65 & -0.51 \\
Risaralda & 0 & 1.74 & -1.74 \\
Santander & 3.78 & 2.97 & 0.80 \\
Sucre & 1.40 & 0.16 & 0.24 \\
Tolima & 17.20 & 0.19 & 1.63 \\
Valle Del Cauca & 7.27 & & \\
Vaupés & 0.14 & .19 & -0.05 \\
Vichada & 0.42 & & \\
No Answer & 0.14 & & \\
\hline \hline & & & \\
\hline
\end{tabular}


Table A-9: Differences in region of origin: Consent vs. no consent (within included)

\begin{tabular}{|c|c|c|c|}
\hline Region & Consent & No Consent & Difference \\
\hline Amazonas & 0 & 0.57 & -0.57 \\
\hline Antioquia & 8.99 & 7.18 & 1.81 \\
\hline Arauca & 2.72 & 1.72 & 1 \\
\hline Atlántico & 0.54 & 1.15 & -0.6 \\
\hline Bogotá & 0.27 & 0.57 & -0.3 \\
\hline Bolívar & 3 & 1.72 & 1.27 \\
\hline Boyacá & 0.82 & 1.72 & -0.91 \\
\hline Caldas & 0.82 & 1.44 & -0.62 \\
\hline Caquetá & 4.9 & 6.03 & -1.13 \\
\hline Casanare & 0.82 & 0.29 & 0.53 \\
\hline Cauca & 4.09 & 2.3 & 1.79 \\
\hline Cesar & 2.18 & 1.72 & 0.46 \\
\hline Chocó & 3 & 3.45 & -0.45 \\
\hline Cundinamarca & 2.45 & 4.02 & -1.57 \\
\hline Córdoba & 3.27 & 4.02 & -0.75 \\
\hline Guajira & 0.82 & 0.86 & -0.04 \\
\hline Guaviare & 1.63 & 2.59 & -0.95 \\
\hline Huila & 10.35 & 10.92 & -0.57 \\
\hline Magdalena & 1.36 & 3.45 & -2.09 \\
\hline Meta & 5.99 & 4.31 & 1.68 \\
\hline Nariño & 5.72 & 7.18 & -1.46 \\
\hline Norte de Santander & 1.36 & 1.72 & -0.36 \\
\hline Putumayo & 2.45 & 2.59 & -0.13 \\
\hline Quindio & 0.27 & 0 & 0.27 \\
\hline Santander & 4.36 & 3.16 & 1.2 \\
\hline Sucre & 0.82 & 2.01 & -1.19 \\
\hline Tolima & 19.62 & 14.66 & 4.96 \\
\hline Valle del Cauca & 6.54 & 8.05 & -1.51 \\
\hline Vaupés & 0.27 & 0 & 0.27 \\
\hline Vichada & 0.27 & 0.57 & -0.3 \\
\hline No Answer & 0.27 & 0 & 0.27 \\
\hline
\end{tabular}


Table A-10: Differences in region of origin: Interviewed vs. not found (within included \& given consent)

\begin{tabular}{lccc}
\hline & & & \\
Region & Surveyed & Not found & Difference \\
\hline \hline & & & \\
Antioquia & 9.85 & 8.51 & 1.34 \\
Arauca & 3.79 & 2.13 & 1.66 \\
Atlántico & 0.76 & 0.43 & 0.33 \\
Bogotá & 0.76 & 0 & 0.76 \\
Bolívar & 0.76 & 4.26 & -3.5 \\
Boyacá & 0.76 & 0.85 & -0.09 \\
Caldas & 0.76 & 0.85 & -0.09 \\
Caquetá & 3.79 & 5.53 & -1.74 \\
Casanare & 0 & 1.28 & -1.28 \\
Cauca & 6.82 & 2.55 & 4.26 \\
Cesar & 0.76 & 2.98 & -2.22 \\
Chocó & 0.76 & 4.26 & -3.5 \\
Cundinamarca & 4.55 & 1.28 & 3.27 \\
Córdoba & 3.03 & 3.4 & -0.37 \\
Guajira & 0 & 1.28 & -1.28 \\
Guaviare & 1.52 & 1.7 & -0.19 \\
Huila & 13.64 & 8.51 & 5.13 \\
Magdalena & 0.76 & 1.7 & -0.94 \\
Meta & 5.3 & 6.38 & -1.08 \\
Nariño & 6.06 & 5.53 & 0.53 \\
Norte de Santander & 1.52 & 1.28 & 0.24 \\
Putumayo & 1.52 & 2.98 & -1.46 \\
Quindio & 0.76 & 0 & 0.76 \\
Santander & 5.3 & 3.83 & 1.47 \\
Sucre & 0.76 & 0.85 & -0.09 \\
Tolima & 21.21 & 18.72 & 2.49 \\
Valle del Cauca & 3.79 & 8.09 & -4.3 \\
Vaupés & 0 & 0.43 & -0.43 \\
Vichada & 0 & 0.43 & -0.43 \\
No Answer & 0.76 & 0 & 0.76 \\
\hline \hline & & & \\
\hline
\end{tabular}


Table A-11: Differences in cause of displacement: RUPD-included vs. not included

\begin{tabular}{lccc} 
Cause of Displacement & RUPD-included & Not-included & Difference \\
\hline \hline & & & \\
Death threat & 76.64 & 77.93 & -1.28 \\
Forced recruitment threat & 11.89 & 7.71 & 4.18 \\
Disappearance of family member & 2.8 & 0.66 & 2.13 \\
Armed combat & 1.4 & 1.73 & -0.33 \\
Spraying & 0 & 0.13 & -0.13 \\
Physical mistreat & 0.7 & 1.33 & -0.63 \\
Mines & 0 & 0.13 & -0.13 \\
Death of family member & 4.2 & 3.32 & 0.87 \\
Deny or restrict access to survival goods & 0.56 & 0.66 & -0.11 \\
Theft of goods by armed actor & 0.56 & 0.53 & 0.03 \\
Kidnap of family member & 0.42 & 0.13 & 0.29 \\
Sexual violence & 0.42 & 0.66 & -0.25 \\
N/A & 0.42 & 5.05 & -4.63 \\
\hline \hline
\end{tabular}

Table A-12: Differences in cause of displacement: Consent vs. no consent (within included)

\begin{tabular}{lccc}
\hline Cause of displacement & Consent & No consent & Difference \\
\hline \hline & & & \\
Death threat & 77.93 & 75.29 & 2.64 \\
Forced recruitment threat & 11.17 & 12.64 & -1.47 \\
Disappearance of family member & 2.72 & 2.87 & -0.15 \\
Armed combat & 1.36 & 1.44 & -0.07 \\
Physical mistreat & 0.27 & 1.15 & -0.88 \\
Death of family member & 4.36 & 4.02 & 0.34 \\
Deny or restrict access to surival goods & 0.27 & 0.86 & -0.59 \\
Theft of goods by armed actor & 0.27 & 0.86 & -0.59 \\
Kidnap of family member & 0.27 & 0.57 & -0.3 \\
Sexual violence & 0.82 & 0 & 0.82 \\
N/A & 0.54 & 0.29 & 0.26 \\
\hline \hline
\end{tabular}


Table A-13: Differences in cause of displacement: Interviewed vs. not found (within included $\&$ given consent)

\begin{tabular}{lccc}
\hline Cause of displacement & Interviewed & Not found & Difference \\
\hline \hline & & & \\
Death threat & 81.06 & 76.17 & 4.89 \\
Forced recruitment threat & 9.09 & 12.34 & -3.25 \\
Disappearance of family member & 2.27 & 2.98 & -0.71 \\
Armed combat & 1.52 & 1.28 & 0.24 \\
Physical mistreat & 0 & 0.43 & -0.43 \\
Death of family member & 4.55 & 4.26 & 0.29 \\
Deny or restrict access to surival goods & 0.76 & 0 & 0.76 \\
Theft of goods by armed actor & 0 & 0.43 & -0.43 \\
Kidnap of family member & 0 & 0.43 & -0.43 \\
Sexual violence & 0 & 1.28 & -1.28 \\
N/A & 0.76 & 0.43 & 0.33 \\
\hline \hline
\end{tabular}

\section{Appendix B Contact consent form}




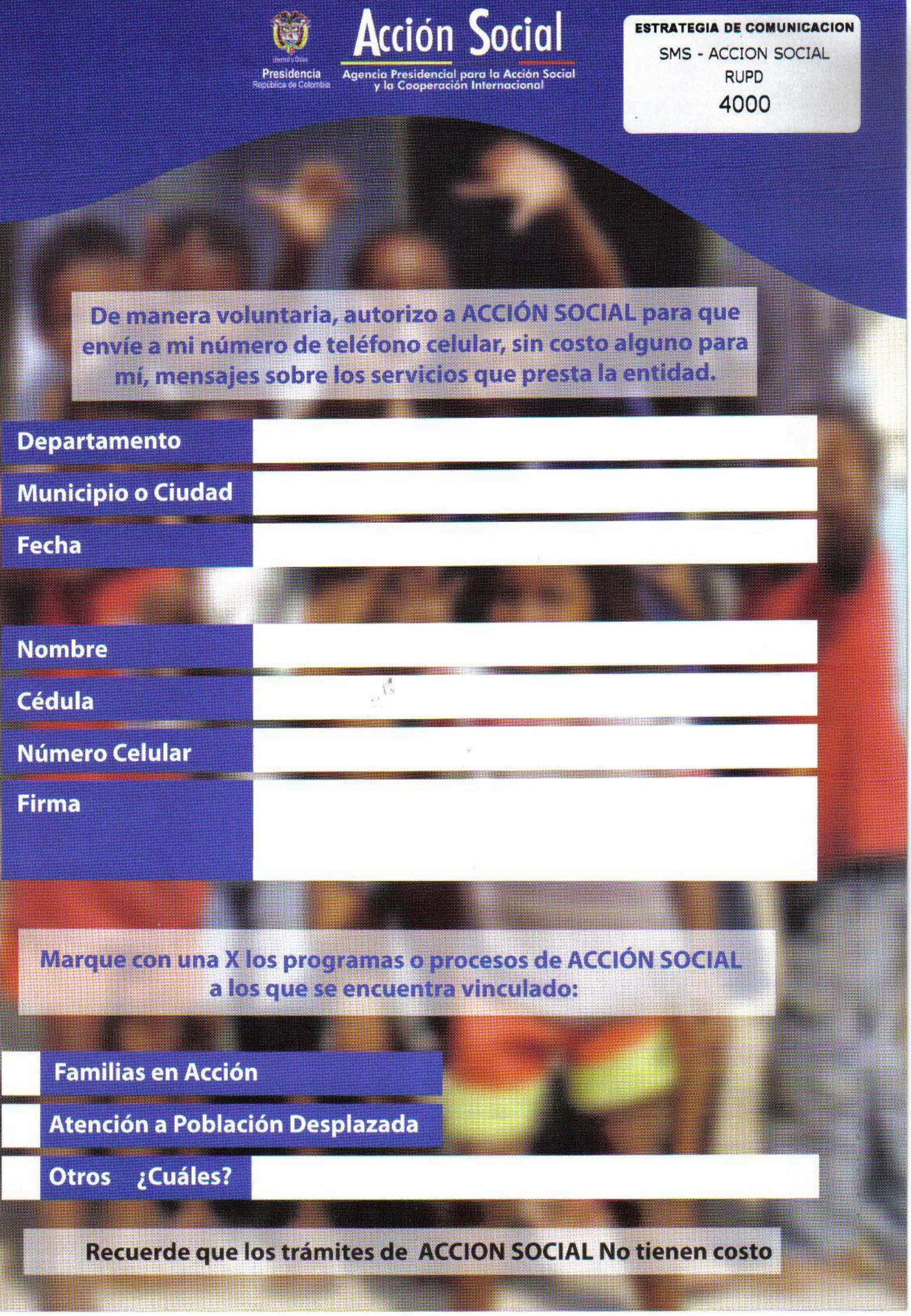

